\title{
$\mathrm{PC} ハ ゚ イ ル の$ 打込み実験*
}

\author{
岡田清** 小野紘一***

\section{Experimental Studies on Concrete Pile Driving}

by

\author{
Kiyoshi Okada and Koichi Ono \\ (Faculty of Engineering, Kyoto University, Kyoto)
}

Recently, concrete piles are driven almost always by blow. This method of driving simplifies the process of construction but sometimes it will have destructive effect on the piles. It is necessary to investigate the process to find out the factors for the destruction of the piles and improve that method.

In this study, RG piles $(\phi 350 \mathrm{~mm} \times 13 \mathrm{~m})$ and PG piles $(\phi 350 \mathrm{~mm} \times 13 \mathrm{~m}+\phi 350 \mathrm{~mm} \times 7 \mathrm{~m})$, both centrifugally spun, were used as test piles, and drop hummers (1t, 2t and $3 t$ ) and diesel hummers (Delmag-12 and Delmag-22) used.

The ground into which the piles were driven has layers of sand $(\mathrm{N}$-value $=15 \sim 20)$ at the depth of $6 \sim 7 \mathrm{~m}$, gravel $(\mathrm{N}$-value $=30 \sim 50)$ at the depth of $12 \sim 13 \mathrm{~m}$ and silt and sand $(\mathrm{N}$-value $=20 \sim 35)$ deeper below.

The impact strains at the head, center and foot of the piles were measured by means of wire strain gauges, and the effects of cussion materials, eccentric blow and the characteristics of ground on the pile stress have also been investigated. Comparative studies were made of some of the theoretical equations for the impact stresses with their experimental results.

Principal conclusions obtained are as follows.

(1) Rebound of a pile increases as the ground becomes harder.

(2) Set per blow decreases as the ground becomes harder and the depth of the set is greater by drop hummers than by diesel hummers.

(3) Delmag-12 cannot drive a pile into the ground which is more than $\mathrm{N}$-value $=50$.

(4) The impact stresses caused by pile-driving ordinarily reach their maximum at the head of the pile and their minimum at the foot of the pile.

(5) The impact stress at the foot of the pile increases as $\mathrm{N}$-value of the ground increases. But the impact stress at the head of the pile is not so related with $\mathrm{N}$-value.

(6) The impact stress at the head of the piles by drop hummers is greater than that by diesel hummers. The former sometimes exceeds the impact strength of RG pile concrete.

(7) The maximum impact stress caused by eccentric blows of both drop hummers and Delmag22 sometimes exceeds the impact strength of the pile concrete. The tensile stress and bending moment due to the eccentric blows sometimes cause cracks in the pile. In these respects, the PC pile is superior to the RC pile, and the diesel hummer is superior to the drop hummer. It is very important to drive a pile as normally as possible and it is necessary to set a proper cussion at the head of the pile.

(8) The impact stress caused by pile-driving should be analyzed by the wave equation rather than by the energy equation.

Further studies are needed of the following problems.

(1) The impact strength of concrete.

(2) The correlation of the compressive strength by the normal test piece and that by the test piece made by the centrifugal force.

(3) Estimation of the impact stress in a pile caused by driving.

(4) Fundamental studies on pile-driving analysis by means of the electric computer.

(Received May 16, 1967)

\footnotetext{
* 原稿受理 昭和42年 5 月 16 日

** 正会員 京都大学工学部 京都市左京区吉田本町

*** 京都大学工学部 京都市左京区吉田本町
} 


\section{1 緒}

\section{言}

今日では，既製鉄筋コンクリートぐいの打込み工法 の大半は打撃によるもので，乙の方法には施工の簡易 さと作業能率の優秀性という長所がある.しかしなが らこの方法は，しばしばくい体を破損させる欠点があ り，施工管理の面で難点がある，そこで打撃によるく い体損傷の原因を明らかにして工法の改良を行なうと ともに，てれらの成果を生かして施工の基準化を図り， 同工法の施工信頼度を高める必要がある.

本実験はハンマ重量の異なるドロップハンマおよび ジーゼルハンマを用いてくいを打ち込み, 打込み時に 生ずる打撃応力を測定するてとによって打撃エネルギ の適正範囲をきわめ，〈い頭保護を目的とするクッシ ョンの効果, くい打ち時に生ずる偏打, 打込み地盤の くい体に及ぼす影響などを明らかにせんとしたもので ある。また，得られた実験結果を考慮して今日まで発 表されたくい打ち時の打撃応力推定式の適合性を検討 した.

\section{$\mathbf{2} \cdot \mathbf{1}$ 供試体の製作}

\section{2 実 験 方 法}

本実験に使用したコンクリートぐいは，わが国の代 表的くいメ一カ一の共同提供に依存したため, 使用材 料やコンクリートの配合，〈いの製造方法などに，各 社によって，わずかの相違があったが，本実験の性質 上，すべて同一のものとみなしてさしつかえないと思 われる、コンクリートの代表的な示方配合は，Table I に示すようであった，後述するようにボーリングに よる土質調査の結果を考慮して，遠心力締固めによっ て造られた RGくいは長さ $13 \mathrm{~m}$ の単くいとし， PGく いは下くい13m，上くい $7 \mathrm{~m} の 2$ 本継ぐいとした。 ま た，くい先端の型としては, 開口型と閉塞型の 2 種が あり，てれらを併用した，供試体の寸法, 型式および 本数を Table II に示す。また，くいと同一配合のコ ンクリートの標準供試体を同時に作成し，圧縮強度測 定用とした.

\section{$2 \cdot 2$ くいの打込み地盤の土質調査}

くいの打込み場所は大阪市東淀川下新庄町内の神崎 川河川㩤で行なった. 本地点のボーリングによる土質 調査の結果はFig. 1のようであった. この結果からわ かるように, 深度 $6 \sim 7 \mathrm{~m}$ 付近に $N$ 值 15〜20の砂層 があり，12〜 $13 \mathrm{~m}$ 付近に $N$ 值 $30 \sim 50$ 程度の硬砂れき

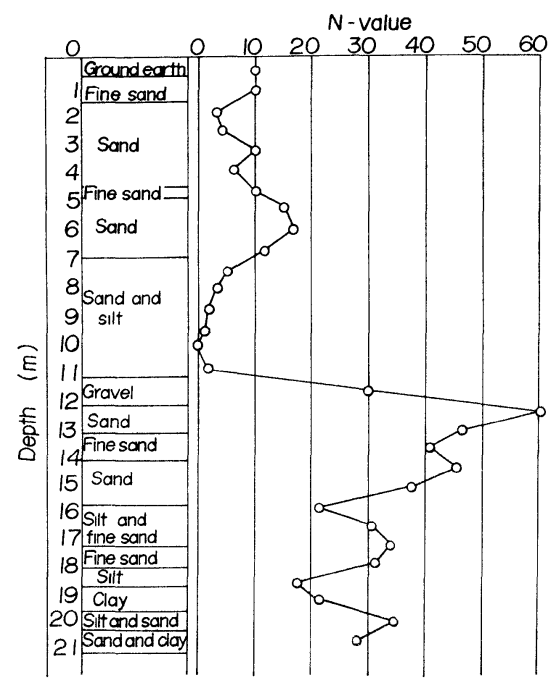

Fig. 1. Soil figure.

Table I. Specified mix proportion of pile concretes.

\begin{tabular}{|c|c|c|c|c|c|c|c|c|}
\hline $\begin{array}{l}\text { Kind } \\
\text { of } \\
\text { pile }\end{array}$ & $\begin{array}{l}\text { Max. size } \\
\text { of coarse } \\
\text { aggregate } \\
(\mathrm{mm})\end{array}$ & $\underset{(\mathrm{cm})}{\text { Slump }}$ & $\begin{array}{l}\text { Weight } \\
\text { of water } \\
\text { per unit } \\
\text { volume of } \\
\text { concrete } \\
W(\mathrm{~kg})\end{array}$ & $\begin{array}{l}\text { Weight } \\
\text { of cement } \\
\text { per unit } \\
\text { volume of } \\
\text { concrete } \\
C(\mathrm{~kg})\end{array}$ & $\begin{array}{l}\text { Water- } \\
\text { cement } \\
\text { ratio } \\
W / G(\%)\end{array}$ & $\begin{array}{l}\text { Absolute } \\
\text { fine agg- } \\
\text { regate } \\
\text { percentage } \\
s / a(\%)\end{array}$ & $\begin{array}{l}\text { Weight of } \\
\text { fine agg- } \\
\text { regate per } \\
\text { unit volume } \\
\text { of concrete } \\
S(\mathrm{~kg})\end{array}$ & $\begin{array}{l}\text { Weight of } \\
\text { coarse } \\
\text { aggregate } \\
\text { per unit } \\
\text { volume of } \\
\text { concrete } \\
G(\mathrm{~kg})\end{array}$ \\
\hline $\mathrm{R} \mathrm{C}$ & 25 & $5-7$ & 160 & 410 & 39 & 37.0 & 685 & 1165 \\
\hline $\mathrm{PC}$ & 25 & $5-7$ & 174 & 470 & 37 & 39.2 & 696 & 1079 \\
\hline
\end{tabular}

Table II. Description of test piles.

\begin{tabular}{c|c|c|c|c|c|c|c}
\hline $\begin{array}{c}\text { Kind of } \\
\text { pile }\end{array}$ & $\begin{array}{c}\text { Length } \\
(\mathrm{m})\end{array}$ & $\begin{array}{c}\text { Outer } \\
\text { diameter } \\
(\mathrm{mm})\end{array}$ & $\begin{array}{c}\text { Thickness } \\
(\mathrm{mm})\end{array}$ & Reinforcement & $\begin{array}{c}\text { Effectıve } \\
\text { prestress } \\
\left(\mathrm{kg} / \mathrm{cm}^{2}\right)\end{array}$ & $\begin{array}{c}\text { Shape of } \\
\text { pile tip }\end{array}$ & $\begin{array}{c}\text { Number of } \\
\text { test piles }\end{array}$ \\
\hline R C & 13 & 350 & 60 & $\phi 13 \mathrm{~mm} \times 11$ & - & Open & 3 \\
\hline P C & $7+13$ & 350 & 60 & $\phi 7 \mathrm{~mm} \times 12$ & 52.7 & Closed & 8 \\
\hline
\end{tabular}


㬝が存在し，その下部は $N$ 値 20 35 程度の砂層およ びシルト周となっている。乙の土質調査結果をくい打 ちの実験地盤として採用するとととする。

\section{$2 \cdot 3$ くいの打込み}

くいの打込みは本体には D-07 H 型万能堀削機を使 用し，ハンマとしては,ドロップハンマは $1 ， 2$ および 3t，ジーゼルハンマとしては，デルマック12（D-12) および22（D-22）在使用した。ドロップハンマの落高 は通常 $2 \mathrm{~m}$ とし，ひずみ測定時は 2 および $3 \mathrm{~m}$ とした。 クッション材としては通常は松板の合板 $(\phi 350 \mathrm{~mm} \times$ $5.5 \mathrm{~mm})$ を $2 \sim 3$ 枚使用し，クッション試験時はゴム を主体とした試験用クッションも使用した。なお，斜 くいは $10^{\circ}$ の傾斜で打込み，偏打は $3^{\circ}$ の斜くい対し てハンマを鉛直に落下させた。

\section{$2 \cdot 4$ 测 定}

動ひずみの測定はビジグラフを使用し, 名深度, 各

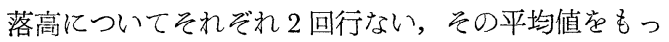
て測定値とした。 ゲージの取り付け位置は Fig. 2 に

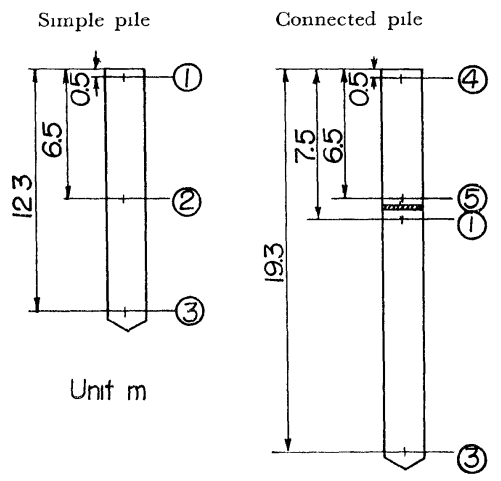

Fig. 2. Location of gauges.

示すように，単くいでは最高 3 断面， 2 本継ぐいでは 最高 4 断面とし，各断面につき周長 4 等分の 4 個所と した．動ひずみ測定時にくいの貫入量およびりバウン ド量を測定し, 通常ドロップハンマでは 2 回, ジーゼル ハンマでは10回の值の平均値をもって測定值とした。 このとき同時にハンマの落高も測定した。なお，くい の打込みに要する打撃回数および所要時間も測定した。

\section{3 実験結果およびその考察}

\section{$3 \cdot 1$ 使用コンクリートの圧縮強度}

くいと同一配合のコンクリートの圧縮強度は Table III のようになった。コンクリートの衝撃強度につい ては充分な資料がないため打込み中のくいのコンクリ 一下衝撃強度を求めることは現状では困難である。才 ーストラリアでは，コンクリートの衝撃強度は $30 \phi$ $15 \mathrm{~cm}$ の円柱供試体の $75 \%$ 程度と考光てよいとしてい る.ししがって，本実験ではオーストラリアの規集に

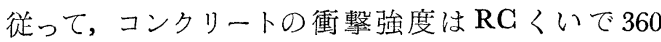

Table III. Compressive strength of concretes $\left(\mathrm{kg} / \mathrm{cm}^{2}\right)$.

\begin{tabular}{c|c|c|c|c|c}
\hline Type & No. 1 & No. 2 & No. 3 & Average & $\begin{array}{c}\text { Impact } \\
\text { strength* }\end{array}$ \\
\hline R C & 475 & 499 & 485 & 486 & 364 \\
P C & 636 & 651 & 600 & 629 & 445 \\
\hline
\end{tabular}

* Calculated values by the Australian standards

$\mathrm{kg} / \mathrm{cm}^{2}, \quad P C$ くで $450 \mathrm{~kg} / \mathrm{cm}^{2}$ 程度と考党るとと にする。なお，解析に用いたくいコンクリートの弾性 係数はRCくいに対し, $3.5 \times 10^{5} \mathrm{~kg} / \mathrm{cm}^{2}, \mathrm{PC}$ くい対 し $4.0 \times 10^{5} \mathrm{~kg} / \mathrm{cm}^{2}$ とした.

\section{$3 \cdot 2$ リバウンド量と打込み地盤との関係}

くいの 1 打撃あたりのリバウンド量と，そのときに くい先端が貫入しつつある地盤の $N$ 值との関係を打 込みハンマ別に求めてみると Fig. 3 のようになった。

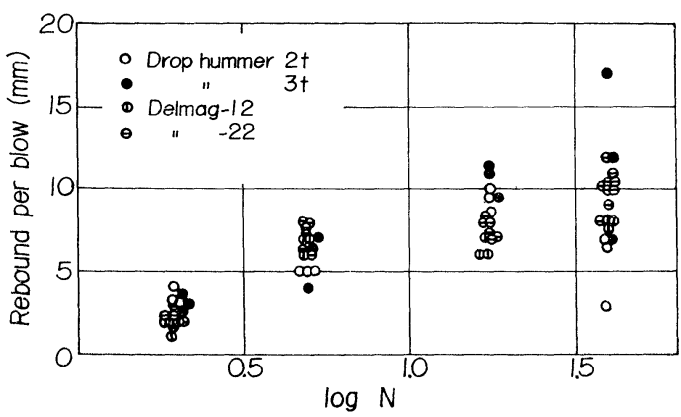

Fig. 3. Relationship between rebound and $\mathrm{N}$-value.

この四からわかるように，N值が増加するとともにり バウンド量も増加し，その増加の割合は $N$ 值が小さ いほど大きいようである。.また， $N$ 值が比較的小さい ときは打込みハンマによるリバウント量には差が少な いが，N值が大きくなると， $3 \mathrm{t}$ ・ドロップハンマやD22 のほうが $2 \mathrm{t} ・$ ドロップハンマや D-12 で打ち込む ときよりもリバウンド量はやや多い。なお $\log N=1.6$ $(N=40)$ 付近のばらつきは深度 $12 \mathrm{~m}$ 付近汇おける $N$ 值 の変化が激しいためであると考觉られる。

\section{$\mathbf{3} \cdot \mathbf{3}$ 貫入量と打込み地盤との関係}

1 打撃あたりのくいの貫入量とそのときにくい先端 が貫入しつつある地盤の $N$ 值との関係を打込みハンマ 別泟求めてみると Fig. 4 の上うになった。乙れによる と， $N$ 值が增加するととも溃入量は明らかに減少す る，貫入量の大きさは $N$ 值が小さいときは打込み八 ンマによる差は大きく， $N$ 値が大きくなるとその差は 小さくなる．貫入量の大きさをハンマ別にみると， $3 \mathrm{t}$ ・ドロップハンマ， D- $22,2 \mathrm{t}$ ・ドロップハンマ， D-12 の順に小さくなる。また，Fig.4亿おいてわかるよう に，同一の $N$ 值に対するくいの貫入量㤬ドロップ八 


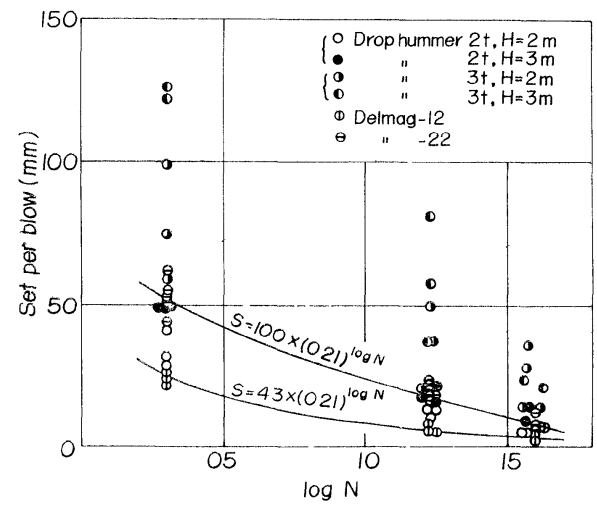

Fig. 4. Relationship between et per blow and $\mathrm{N}$-value.

ンマを使うとばらつきがちであるが，ジーゼルハンマ を使うとばらつきがほとんどない，そこでジーゼルハ ンマを使った場合の貫入量 $S(\mathrm{~mm})$ と $N$ 值との関係 を, 次の実験公式を仮定して数式表現を行なった.

$$
S=c a^{\log N}
$$

こてで $c, a$ は実験值より求まる定数であって $c>0$, $0<a<1$ である.

D-12 を使用した場合

$$
S=43 \times(0.21)^{\log N}
$$

D-22 在使用した場合

$$
S=100 \times(0.21)^{\log N}
$$

となった．乙の結果より，実験的には D-12 と D-22 の $a$ の值は同じになった。 したがって，D-12 を使用 した場合の 1 打撃あたりのくいの貫入量は，D-22 を 使用した場合の $40 \sim 45 \%$ 程度であり，乙の値は地船の $N$ 值に無関係である。

\section{3・4 リバウンド量と打撃応力}

リバウンド量と打撃応力の関係を使用した打込みハ ンマ别に求めた結果, Fig. 5 および 6 のようになった. これらの図からわかるように，リバウンド量が増加す るとともにくい内に生ずる打撃応力は，〈い頭では変 化が少ないが，くい先端では比較的大きく増加してい 万.

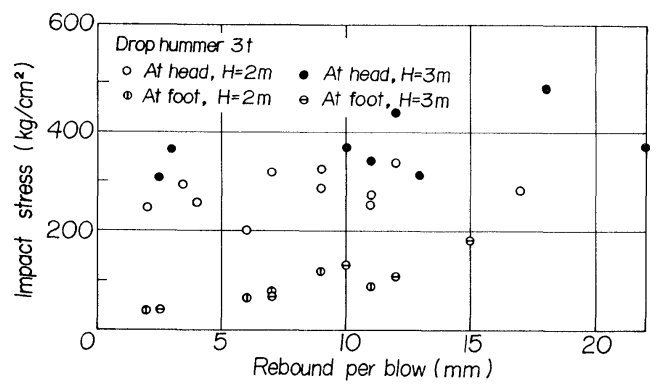

Fig. 5. Relationship between rebound and impact stress.

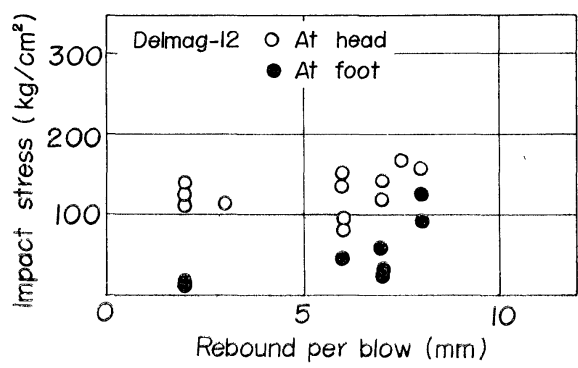

Fig. 6. Relationship between rebound and impact stress.

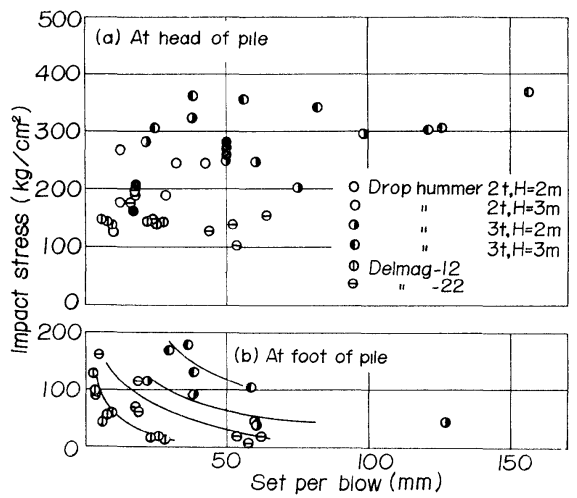

Fig. 7. Relationship between set per blow and impact stress.

\section{3 -5 貫入量亡打撃応力}

Fig. 7 は，使用ハンマ別に 1 打撃あたりのくいの買 入量とくい頭およびくい先端の打撃応力との関係を求 めたものである。この罒からわかるように，〈い頭に 生ずる打撃応力はくいの貫入量とあまり関係がないよ うであるが，くい先端に生ずる打撃応力は貫入量の增 加とともに減少するてとがわかる。乙れは前述したよ うに，貫入量が多いというととはくい先端が貫入しつ つある地盤が軟弱であり，そのためくいの先端抵抗が 小さくなり，また貫入量が多いために，摩擦によって 失なわれるエネルギが大きくなり，〈い頭における応 力には変化が少ないが，〈い先端における応力は減少 するからであろう。

\section{$3 \cdot 6$ 地盤亡打撃応力}

Fig. 8 はくい頭およびくい先端に生ずる打撃応力と $N$ 值との関係を求めたものである。乙の図によると $N$ 值によるくい頭応力の変化は小さいが，くい先端の応 力は $N$ 值の増加とともに増加している．前述したよ うに，リバウンド量の増加と $N$ 值の増加が相伴うこ とと, くい先端の応力の増加とリバウンド量の増加が 相伴うことを考え合わせれば，〈い先端の応力の増加 が $N$ 值の増加に関係することがわかる。

$\mathbf{3} \cdot \boldsymbol{7}$ 打込みハンマと打撃応力 


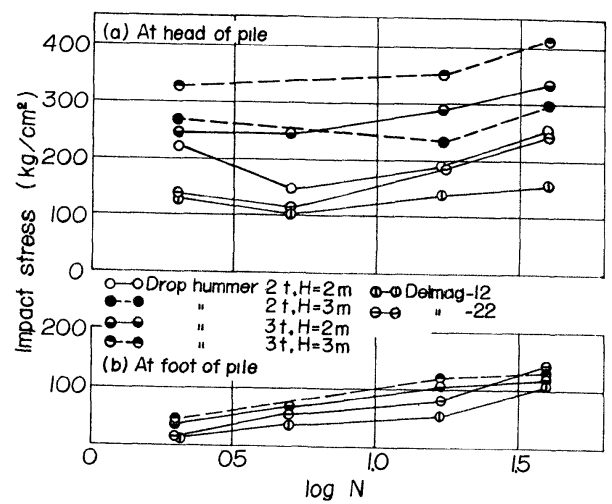

Fig. 8. Relationship between impact stress and $\mathrm{N}$-value.

Table IV は各断面に生じた平均的打撃応力を打込 みハンマ別に求めたものである。また，Table V は D-12 を基隼としたときの各ハンマによって生ずるく い頭応力の割合である。乙れらからわかるように打撃 応力はくい頭で最大であり，その大きさは， $3 \mathrm{t} ・$ ドロ ップハンマを使って落高 $3 \mathrm{~m}$ とすると $300 \mathrm{~kg} / \mathrm{cm}^{2}$ 以
上となり，400 $\mathrm{kg} / \mathrm{cm}^{2}$ を越光る場合も生ずる。 $2 \mathrm{~m}$ の落高では250～ $350 \mathrm{~kg} / \mathrm{m}^{2}$ となっている．2t・ドロッ プハンマを使って落高 $3 \mathrm{~m}$ とすると $250 \sim 300 \mathrm{~kg} / \mathrm{cm}^{2}$ となっており，2 m落高では 150〜 $250 \mathrm{~kg} / \mathrm{cm}^{2}$ となっ ている、D-22 を使用した場合は深度 $12 \mathrm{~m}$ 程度までは 130〜 $250 \mathrm{~kg} / \mathrm{cm}^{2}$ であるが，19m まで打ち込む間に は350 $\mathrm{kg} / \mathrm{cm}^{2}$ 程度になることがある。D-12 を使用し た場合は $100 \sim 150 \mathrm{~kg} / \mathrm{cm}^{2}$ の低応力に収まるようであ る、D-12 を規準として，各ハンマによって生ずる応 力の平均的割合を比べてみると，D-22 は約 1.4 倍， $2 \mathrm{t}$ ・ドロップハンマの落高 $2 \mathrm{~m}$ で約 1.6 倍, $3 \mathrm{~m}$ 落高 で1.9倍, $3 \mathrm{t}$ ・ドロップハンマの $2 \mathrm{~m}$ 落高で約 2.0 倍, $3 \mathrm{~m}$ 落高とすると 2.5 倍にも達している.したがって， 打撃応力の面で考えると，ドロップハンマよりもシー ゼルハンマでくい打ちを行なうほうが有利である。な お， Table V からわかるように，くい頭応力はほぼ ハンマの落高の平方根に比例するが，ハンマ重量の平 方根とは比例関係にないようである.

\section{$3 \cdot 8$ 偏打の打撃応力に及ぼす影響}

3・7で述べた打撃応力の值は断面の平均值であって,

Table IV. Impact stresses $\left(\mathrm{kg} / \mathrm{cm}^{2}\right)$.

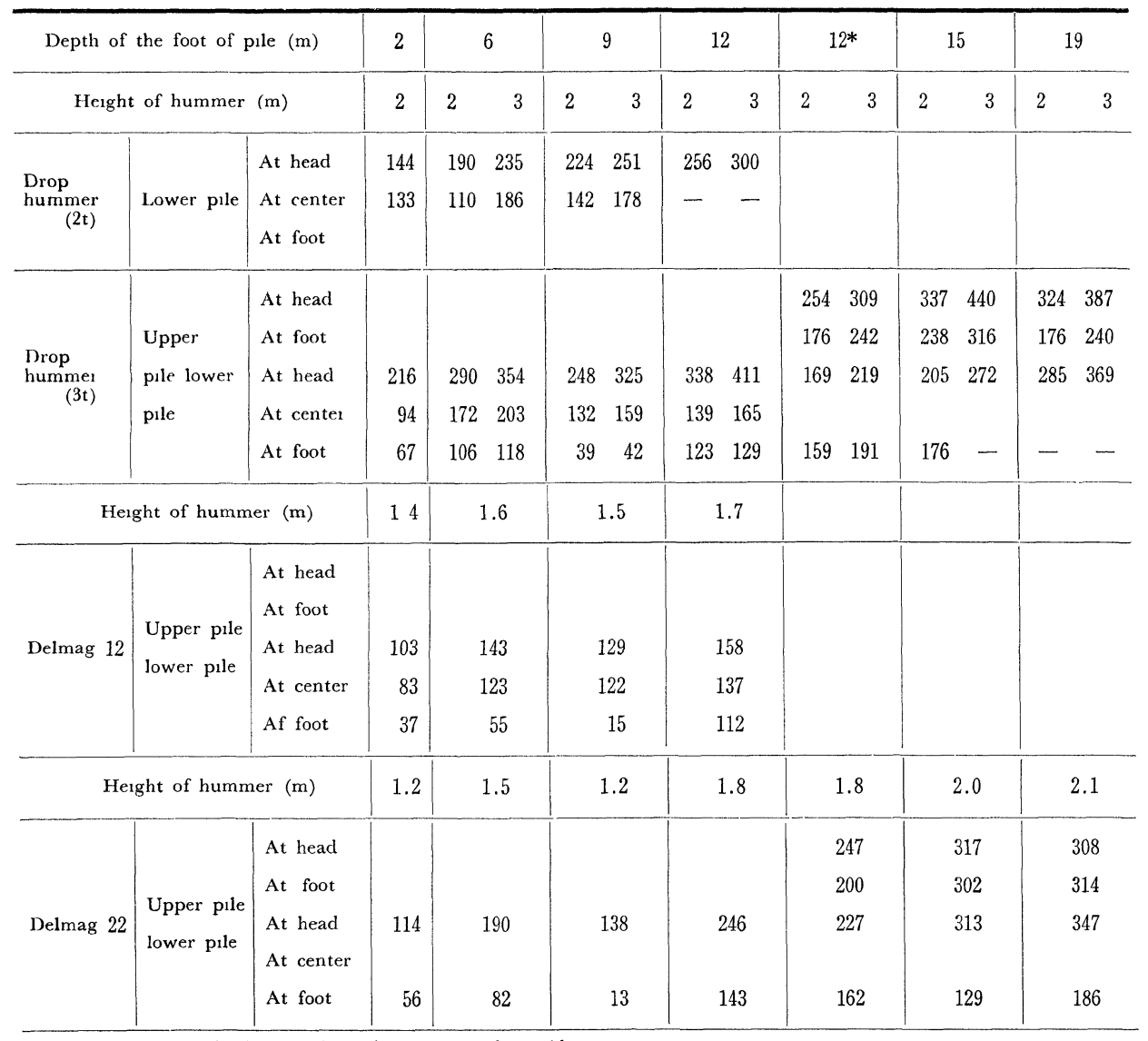

* After connecting the lower pile with upper one by welding 
Table V. Comparison of impact stresses at the head of piles caused by the hummers.

\begin{tabular}{|c|c|c|c|c|c|}
\hline \multirow{2}{*}{ Hummer } & \multirow{2}{*}{$H(\mathrm{~m})$} & \multicolumn{3}{|c|}{$\begin{array}{l}\text { Depth of the foot of pile } \\
(\mathrm{m})\end{array}$} & \multirow{2}{*}{ Averages } \\
\hline & & 6 & 9 & 12 & \\
\hline Delmag-12 & 1.6 & 1.00 & 1.00 & 1.00 & 1.00 \\
\hline Delmag-22 & 1.5 & 1.33 & 1.17 & 1.55 & 1.35 \\
\hline \multirow{2}{*}{$\begin{array}{l}\text { Drop } \\
\text { hummer } \\
\qquad(2 t)\end{array}$} & 2.0 & 1.33 & 1.73 & 1.62 & 1.56 \\
\hline & 3.0 & $\begin{array}{l}1.64 \\
(1.23)\end{array}$ & $\begin{array}{l}2.06 \\
(1.19)\end{array}$ & $\begin{array}{l}1.90 \\
(1.17)\end{array}$ & $\begin{array}{l}1.87 \\
(1.20)\end{array}$ \\
\hline \multirow{2}{*}{$\begin{array}{l}\text { Diop } \\
\text { hummer } \\
\qquad(3 t)\end{array}$} & 2.0 & 2.03 & 1.92 & 2.14 & 2.03 \\
\hline & 3.0 & $\begin{array}{l}2.50 \\
(1.23)\end{array}$ & $\begin{array}{l}2.52 \\
(1.31)\end{array}$ & $\begin{array}{l}2.60 \\
(1.22)\end{array}$ & $\begin{array}{l}2.54 \\
(1.25)\end{array}$ \\
\hline
\end{tabular}

Values in parentheses are the ratıo of impact stress $(H=3 \mathrm{~m})$ to that $(H=2 \mathrm{~m})$

\section{この值はくいがまったく偏心せずに打ち込まれた場合} の值に相当する。しかしながら，施工上の点からして， 偏打なしにくいを打ち込むととは不可能に近いと考え られる. 偏打によって断面に生ずる打撃応力は不均一 となるが，いま，一断面四つの測定值より理論的に求 めた断面応力の最大のものを推定最大応力とし，乙れ を Table VI および Fig. 9 に示す. Fig. 9 からわか るように, $3 \mathrm{t} ・$ ドロップハンマ以外のハンマで打ち込 む場合は，平均応力ではその最大応力がくいのコンク リートの衝撃強度を越すととはないが，Table VI に

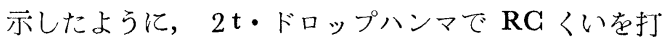
ち込む場合には，偏打による最大打撃応力がくいのコ ンクリートの衝撃強度を越す場合が生じており, D-22 を使用した場合にも，継ぐいではこの傾向が生じてい る。また，偏打によってくいに引張応力が生じ，その

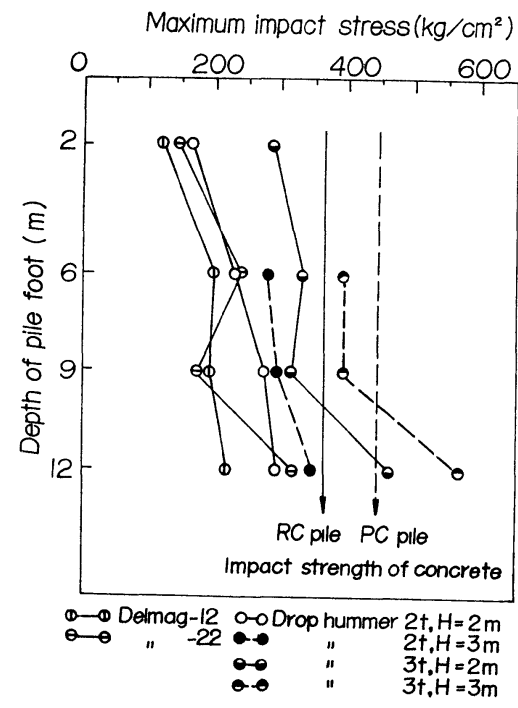

Fig. 9. Maximum impact stress at head of pile.

大きさが $100 \mathrm{~kg} / \mathrm{cm}^{2}$ 近くになるととも測定された。 コンクリートの引張強度は約 $50 \mathrm{~kg} / \mathrm{cm}^{2}$, 有効プレ

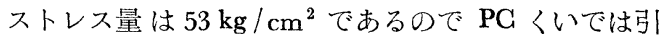
浸応力によってひびわれがはいるととはほとんどない が，RGくいではひびわれがはいったと推測される。

\section{$3 \cdot 9$ くい打ち時に生ずる曲げモーメント}

Fig. 10 は，〈い打込み時の偏打によって生じた曲 げモーメントである。正常打の場合には， $3 \mathrm{t} ・$ ドロ ップハンマ以外のハンマを使用すると，曲げモーメン トは，常に設計ひびわれ発生モーメント $(3.6 \mathrm{t} ・ \mathrm{~m})$ 以下に収まるようである， $3^{\circ}$ の偏打を行なった場合に は，D-12 使用しても，〈いに生ずる曲げモーメン トの值は，常に設計ひびわれ発生モーメントを越え，

Table VI. Maximum impact stresses $\left(\mathrm{kg} / \mathrm{cm}^{2}\right)$.

\begin{tabular}{l|c|c|c|c|c|c|c|c|c|c|c}
\hline $\begin{array}{c}\text { Depth of the foot of } \\
\text { pile (m) }\end{array}$ & 2 & 6 & 9 & 12 & 12 & 15 & 16 & 18 & 19 \\
\hline Delmag-12 & $\begin{array}{c}150 \\
(120)\end{array}$ & $\begin{array}{c}208 \\
(198)\end{array}$ & $\begin{array}{c}209 \\
(188)\end{array}$ & $\begin{array}{c}236 \\
(216)\end{array}$ & 216 & - & - & - & - \\
\hline Delmag-22 & $\begin{array}{c}189 \\
(144)\end{array}$ & $\begin{array}{c}312 \\
(235)\end{array}$ & $\begin{array}{c}259 \\
(171)\end{array}$ & $\begin{array}{c}386 \\
(317)\end{array}$ & 383 & 402 & 392 & 421 & 421 \\
\hline $\begin{array}{c}\text { Drop hummer } \\
(2 \mathrm{t})\end{array}$ & $H=2 \mathrm{~m}$ & $\begin{array}{c}185 \\
(159)\end{array}$ & $\begin{array}{c}369 \\
(233)\end{array}$ & $\begin{array}{c}304 \\
(273)\end{array}$ & $\begin{array}{c}428 \\
(292)\end{array}$ & - & - & - & - & - \\
\hline
\end{tabular}

Values in parentheses are averages 


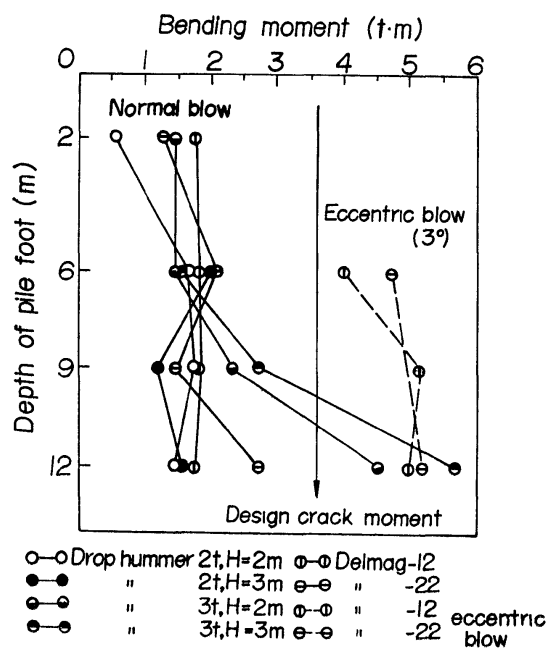

Fig. 10. Bending moment at head of pile.

そのため，くいには曲げによるひびわれがはいったる 考えられる。しかし，本実験では，くい亿生じた曲け モーメントの值が破壊モーメント $(8.1 \mathrm{t} \cdot \mathrm{m})$ の值ほ どにはなっておらず，したがって，〈いが偏打によっ て曲げ破壊を起こすととは少ないと考えられる。

\section{3・10 クッションの効果}

くいを打ち込むときにくい頭に適当なクッションを 用いると，ハンマがクッションを通してくいに接触す る持続時間が長くなり，その結果，ハンマからくいに 与えられるエネルギの授受時間が長くなって応力の緩 和を行ない，くい頭の保護ができると考えられる。本 実験ては，ゴムを主体とした数種のクッションの試験 を行なったが，松板クッションに比べて，応力緩和， 耐久性, コストの点で特にすぐれたものはなかった。 しかしながら, クッションを使用すると, 貫入量は減 少するが，偏打が少なくなるととが琹められた。

\subsection{1 応力の伝ぱ}

くい先端の応力とくい頭の応力の比を百分率で表わ して，乙れを応力伝達率 $\alpha(\%)$ と呼び，乙れと $N$ 值 との関係を求めたものが Fig. 11 である。乙の図から 明らかなように $N$ 值が減少するにつれて $\alpha$ も減少し

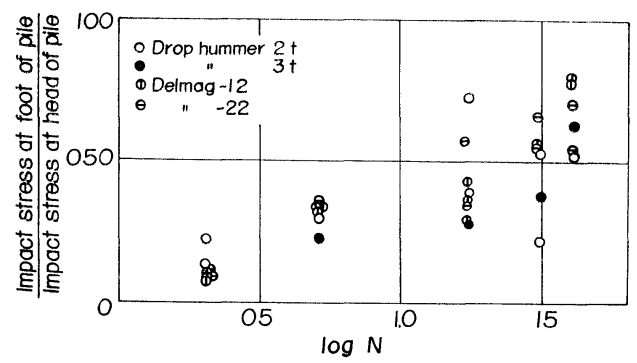

Fig. 11. $\frac{\text { Impact stress at foot of pile }}{\text { Impact stress at head of pile }}-\mathrm{N}$-value.
ている。乙れは $N$ 值が小さくなると，貫入量が多く なり, 周面の摩擦によって失なわれるエネルギが大と なり，かつくい先端で反射してくる応力波が，圧縮よ りもむしろ引張りとして反射してくるためであると考 えられる。

\section{4 くい打ち時の打撃応力の推定}

かっては，くい打ちをあきらめたような堅く締まっ た中間㐿を打ち抜いて，さらに下方の硬質風にまでく いな打ち込むようになった現在においては，コンクリ 一トぐいの材質が改良されてその強度が大きくなった とはいえ，くいの破壊に関しててれまで問題にならな かったくい打ち時の打撃応力が問題となり，〈い打ち 機の選択が重要となってきた。 そのためにはくい打ち 㭙に生ずる打撃応力の推定が必要である．打撃応力の 推定には主として打撃エネルギのつりあいに基づくう 法と，波動方程式に基づく方法とがある。

\section{$\mathbf{4} \cdot \mathbf{1}$ 打撃エネルギのつりあいによる方法 ${ }^{2}$}

との方法はハンマの放出した有効エネルギとハンマ の打撃力がその僢間に行なう仕事の量と等しいという 仮定に基づいている。〈い頭応力 $\sigma$ は，

$$
\sigma=\sqrt{\frac{2 e E W H}{A L}}
$$

ここで, $W:$ ハンマ重量 $(\mathrm{kg})$

$$
\begin{aligned}
& H: \text { ハンマの落高 }(\mathrm{cm}) \\
& A: \text { くいの断面積 }\left(\mathrm{cm}^{2}\right) \\
& L: \text { くの長さ }(\mathrm{cm}) \\
& E: \text { くの弾性係数 }\left(\mathrm{kg} / \mathrm{cm}^{2}\right) \\
& e: \text { 打撃効率 }
\end{aligned}
$$

いま，(4)式によって， RC 13m〈いけついて，ドロ ップハンマの $1 ， 2$ および $3 \mathrm{t}$ を使って落高をそれぞ れ $1 ， 2$ および $3 \mathrm{~m}$ としたときの打撃応力を求めてみ ると Table VII のようになる。 なお $e=0.6$ として

Table VII. Impact stresses calculated by the energy equation.

\begin{tabular}{c|c|c|c}
\hline$W$ & 1 & 2 & 3 \\
\hline 1 & 242 & $344(236)$ & $421(280)$ \\
2 & 344 & $484(256)$ & $598(300)$ \\
3 & 421 & $598(338)$ & $726(411)$ \\
\hline
\end{tabular}

Values in parentheses ate experimental values unit : $\left(\mathrm{kg} / \mathrm{cm}^{2}\right)$

$H$ : Hummer height (m) $W$ : Hummer weight (t)

計算を行なった。乙れによると打撃エネルギが $3 \mathrm{t} \cdot \mathrm{m}$ 以上に対して推定打撃応力は $420 \mathrm{~kg} / \mathrm{cm}^{2}$ 以上の高応 力となっており，実験值との差が非常に大きい，乙れ はハンマによる打撃力か瞬間的にくい全体に一様に働 き，その大きさが等しいと仮定しているからであると 考えられ，乙の仮定は実験結果と矛盾するからである。 
$4 \cdot 2$ 波動方程式に基づく方法(その 1 )

$$
\sigma=\frac{\sqrt{2 e E_{p} \rho_{p} H}}{\left(1+\frac{A_{C}}{A_{H}} \sqrt{\frac{E_{C} \rho_{C}}{E_{H} \rho_{H}}}\right)\left(1+\frac{A_{P}}{A_{C}} \sqrt{\frac{E_{P} \rho_{p}}{E_{C} \rho_{C}}}\right)}
$$

とこで,

$A_{H}, A_{C}, A_{P}$ : ハンマ, クッション, くいの断面積

$E_{H}, E_{G}, E_{P}:$ " "の弾性係数

$\rho_{H}, \rho_{C}, \rho_{P}: "$ " "単位体積重量

(5)式において，打撃㡻力は，ハンマの落高の平方根に 比例するが, ハンマの重量には無関係となっている。 がハンマの落高の平方根に比例するととは本実験にお いても認められたが，ハンマ重量に関係しないという ことは実験とは大いに矛盾する。乙の点が(5)式の難点 である.

\section{$\mathbf{4} \cdot \mathbf{3}$ 波動方程式に基づく方法（その 2$)^{3)}$}

$p^{2}>n^{2}$ のとき，

$$
\sigma=\frac{K V}{A P} \exp \left(-\frac{n}{\sqrt{p^{2}-n^{2}}} \sin ^{-1} \frac{\sqrt{p^{2}-n^{2}}}{p}\right)
$$

$p^{2}<n^{2}$ のとき，

$$
\sigma=\frac{K V}{A P} \exp \left(-\frac{n}{\sqrt{p^{2}-n^{2}}} \sinh ^{-1} \frac{\sqrt{p^{2}-n^{2}}}{p}\right)
$$

ここで,

$$
\begin{aligned}
& n=\frac{K}{2 A} \sqrt{\frac{g}{E_{\gamma}}}, \quad p=\sqrt{\frac{K g}{W}}, \quad K=\frac{A_{C} E_{C}}{t_{C}} \\
& g: \text { 重力の加速度 } \\
& \gamma: \text { クイの単位体積重量 } \\
& W: \text { ハンマ重量 }
\end{aligned}
$$

$t_{\sigma}, A_{C}, E_{C}$ : クッションの厚さ, 断面積, 弹性係数, 実験で用いた RC単くいと同条件のくいについて，ド ロップハンマを使用して打ち込んだ場合の推定打揧応

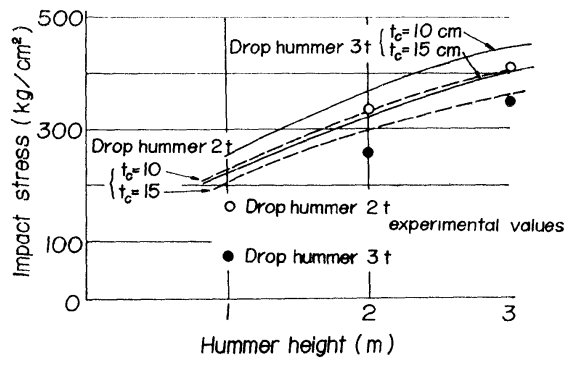

Fig. 12. Impact stress values calculated by the wave equation.
力を上式を使って求めた結果，Fig.12のようになった。 なお，松板クッションの厚さ $t_{C}$ は $10 \sim 15 \mathrm{~cm}$ とし， $E_{C}=1600 \mathrm{~kg} / \mathrm{cm}^{2}, A_{C}=960 \mathrm{~cm}^{2}, \gamma=0.0025 \mathrm{~kg} / \mathrm{m}^{3}$ とし た. Fig. 12 で推定值は実験值より $20 \%$ 程度大きい， てれは，上式を求めるにあたって，〈い体は中実均質 であると仮定しているが，実験に用いたくいは中空で あり仮定仅するからである。つまり理論值は $A=$ $550 \mathrm{~cm}^{2}$ (くい径 $26.5 \mathrm{~cm}$ ) の中詰断面のくいと同し 值となっているため，実際に用いたくいとは条件が異 なっている，ての点に留意すれば上式は打撃応力の推 定式として実際への適合度はかなり高いと考光られる。

\section{5 結 ひ}

打撃打込みによるくい打ち工事では，使用くいは PG くいが有利であり，普通の地盤では，打撃応力， 施工能率の点で, 使用ハンマはジーゼルハンマがよく, 中口径のくいでは D-22 が最も適当である。また施工 管理の面では，〈いはできるかぎり正常に打ち込むこ とがかんじんであり，そのためにも，〈い頭には適当 なクッションが必要である. 打撃応力推定式としては, 現在までのところ，(6)および(7)式が最も適合度がよい と思われる。今後の研究課題としては，コンクリート の衝撃強度わよび打撃による教学のための強度㞶化， 梆準供試体と中空门筒供試体との強度相関関係, くい の打撃応力の推定，電子計算機老利用したくいの打撃 応力解析などが考壳られる。

なお，本研究には建設省より建設技術研究補助金を 交付され，また，コンクリートポールパイル茄会より 多大の援助を得た。乙てに厚人感謝する。

(昭和142年 5 月 28 日 土木学会第22回年次学術講演会にて講湍)

\section{参 考 文 献}

1) Recommended Practices for the Driving of Prestressed Concrete Piles, Cement and Concrete Association of Australia (May 1963).

2) コンクリートポールパイル協会，コンクリートパ イルハンドブック（1966）。

3) Hirsh, T.J., Highway Research Record, 147, p. 24 (1966).

4) Fox, E.N., Engineering, p.263 (Sept. 2, 1932). 